\title{
The Effects of Conditioning Strawberry Plug Plants under Altered Red/Far-red Light Environments
}

\author{
Brent L. Black ${ }^{1}$ \\ Fruit Laboratory, Henry A. Wallace Beltsville Agricultural Research Center, \\ Agricultural Research Service, United States Department of Agriculture, \\ Beltsville, MD 20705-2350
}

\author{
Harry J. Swartz and Gerald F. Deitzer \\ Natural Resource Science and Landscape Architecture Department, University \\ of Maryland, College Park, MD 20742
}

\author{
Bryan Butler \\ Carroll County Extension, Maryland Cooperative Extension Service, \\ Westminster, MD 21157
}

\section{Craig K. Chandler}

University of Florida, Gulf Coast Research and Education Center, Dover, FL 33527

\section{Additional index words. Fragaria, photoperiod, day length, phytochrome}

\begin{abstract}
The effect of altered red/far-red light environment on subsequent field performance of strawberry plug plants was tested. Two wavelength-selective plastic films were compared to neutral shade and full-sun control for conditioning 'Chandler'strawberry plug plants before transplanting to a winter production system. The following year, plug plants of 'Chandler', 'Sweet Charlie', and 'Allstar' were conditioned under the same treatments, with the addition of a continuous incandescent light and a short-day photoperiod, and plant performance was followed in the winter production system in Florida, a cold-climate annual hill system in Maryland, and in a low-input greenhouse production system. During the first year, the red light-filtering film slightly advanced fruiting in Florida. However, during the second year, the effect of the red light-filtering film was not significant, and a short-day treatment resulted in a greater reduction in runnering and increased early crown and flower development. For June-bearing strawberry plants maintained above $20^{\circ} \mathrm{C}$, altering the red/far-red environment did not consistently advance flowering.
\end{abstract}

The June-bearing strawberry is generally classified as a facultative short day plant (SDP) (Darrow, 1936; for reviews see Darnell et al., 2003; Durner and Poling, 1988). Flower bud formation is promoted under short days $(<10$ $h)$, but can also occur under long days when temperatures are lower than $16^{\circ} \mathrm{C}$ (Durner et al., 1984; Hartmann, 1947). The minimum temperature/maximum day length for flower bud initiation likely varies among cultivars (Darrow, 1955a, 1955b; Sonsteby and Nes, 1998). Conversely, stolon or runner emergence generally occurs under days longer than $10 \mathrm{~h}$ and temperatures above $20{ }^{\circ} \mathrm{C}$. Durner et al. (1984) showed that under a range of conditions, runner production is inversely related to inflorescence development.

Received for publication 9 Dec. 2004. Accepted for publication 13 Feb. 2005. Mention of a trademark, proprietary product, or vendor does not constitute a guarantee or warranty of the product by the U.S. Dept. of Agriculture and does not imply its approval to the exclusion of other products or vendors that may be suitable. We gratefully acknowledge the work of student interns Matthew Stevens and Emma Wallace for their assistance in plug conditioning and environmental monitoring. We thank Nihal Rajapakse, Clemson University, for providing samples of SXE-4 and YXE-10 photoselective films.

1E-mail blackb@ba.ars.usda.gov. of between 2.5 and 5.0, while incandescent light produces a ratio of about 0.7 .

New methods have been developed for efficiently altering the light environment of the plant. Specialty greenhouse films have been developed that preferentially filter specific wavelengths allowing for altered $\mathrm{R} / \mathrm{FR}$ light environments (Rajapakse et al., 1999). One application of this technology is to grow plants under shade conditions but without the increased internode length associated with shade avoidance, by filtering out FR light (Runkle and Heins, 2001).

In the southeastern and mid-Atlantic states, strawberry plug plants are used in the annual hill production systems to provide sufficient growth through the fall and winter to achieve a profitable number of flower trusses. In this case, runner growth is unwanted and requires costly hand removal, and excessive runnering delays development of branch crowns and flower buds. In Florida's winter production system, plug plants have been used to provide early growth and earlier production. Post-transplant foliar applications of the plant growth regulator prohexadione-Ca have been demonstrated to effectively suppress runners of fall planted plug plants (Black, 2004), but this material is not registered for use on strawberry, and post transplant applications may delay fruiting in the Florida winter production system (Duval, unpublished data).

Plug plants are often produced in protected cultivation, in greenhouses or shade structures, providing an opportunity for manipulating growth to optimize early yields (Bish et al., 2001; Hokanson et al., 2004). The purpose of the present work was to evaluate altered R/FR environments for conditioning strawberry plug plants before transplanting them to three different production systems. The production systems included Florida winter production, an annual hill system in the mid-Atlantic U.S., and a low-input greenhouse production system. If altering the light environment is sufficient to suppress runnering and advance flowering, it would likely be more cost effective than other types of environmental manipulation, such as lowering the growing temperature. Based on the results of Collins and Barker (1964), we expected a red-light absorbing filter would advance fruiting while a far-red absorbing filter would delay fruiting.

\section{Materials and Methods}

eaves can reduce this to a ratio as low as 0.2 (Holmes and Smith, 1977). Electrical discharge lamps (fluorescent, high pressure sodium and metal halide) used in greenhouse and growth chamber lighting have a very high $\mathrm{R}$ to $\mathrm{FR}$ ratio

Florida: Year 1. Samples of two wavelength-selective greenhouse films were tested to evaluate the effects of conditioning

Table 1. Properties of light-filtering films and lighting filter treatments used for conditioning strawberry plug plants.

\begin{tabular}{lcccc}
\hline Property & Noon Sun & Lee $115^{z}$ & AR $^{\mathrm{y}}$ & AFR $^{\mathrm{y}}$ \\
\hline PAR $^{\mathrm{x}}\left(\mu \mathrm{mol} \cdot \mathrm{m}^{-2} \cdot \mathrm{s}^{-1}\right)$ & 961 & 319 & 669 & 633 \\
Shading $^{\mathrm{w}}(\%)$ & 0 & 66.8 & 30.4 & 34.1 \\
Red/far red $(660 / 730)$ & 1.062 & 0.054 & 0.781 & 1.566 \\
\hline
\end{tabular}

${ }^{\mathrm{z}}$ Lighting and photographic filter.

yPhotoselective experimental greenhouse films that preferentially filter red (AR, SXE-4) and far-red (AFR, YXE-10) light.

${ }^{x} \mathrm{PAR}=$ photosynthetically active radiation $(400$ to $700 \mathrm{~nm})$.

wPAR was measured through each of the filters as compared to full sun to calculate shading. 
Table 2. Mean daily maximum and minimum air and soil temperatures in treatment frames for the 2001-02 study. Means represent measurements taken from 18 Sept. to 4 Oct. The Lee 115 is a photographic film that filters red light, but also reduces photosynthetically active radiation (PAR) by $65 \%$.

\begin{tabular}{lllll}
\hline & \multicolumn{2}{c}{ Soil } & & \multicolumn{2}{c}{ Air } \\
\cline { 2 - 3 } \cline { 5 - 5 } Treatment & Max & Min & Max & Min \\
\hline Unfiltered sunlight & 25.2 & 17.8 & 29.2 & 17.9 \\
Red light filtering film & 27.5 & 19.0 & 29.8 & 19.4 \\
Far-red light filtering film & 26.4 & 19.0 & 29.9 & 19.2 \\
Neutral shade, 30\% & 26.2 & 19.1 & 29.2 & 19.1 \\
Lee 115 & 25.7 & 19.2 & 30.2 & 19.0 \\
Neutral shade, 65\% & 25.0 & 19.1 & 27.6 & 19.1 \\
\hline
\end{tabular}

strawberry plug plants under altered R/FR environments on subsequent field performance. Samples of red light absorbing (AR) and farred light absorbing (AFR) films were obtained from Matsui Chemicals (SXE-4, and YXE-10, respectively; Yokohama, Japan; For a detailed description of these films see Rajapakse et al., 1999). For an additional treatment, a red-light absorbing photographic filter was used (115 Peacock Blue, Lee Filters, Hampshire, England). The Lee 115 filter is more efficient than the AR greenhouse film at filtering red light, but also reduces total PAR by $65 \%$ compared to $30 \%$ for the greenhouse film (Table 1).

The two greenhouse films were used to cover the sides and top of frames constructed of PVC pipe measuring $90 \mathrm{~cm}$ on each side. These covered frames were placed on expanded metal benches in a glass-covered greenhouse at the Henry A. Wallace Beltsville Agricultural Research Center in Beltsville, Md. Air temperature in the greenhouse was kept below $30{ }^{\circ} \mathrm{C}$ using fan and pad cooling. To ensure air flow and temperature uniformity, each covered frame was equipped with a single electric fan in the top corner to exhaust air to the outside of the enclosed frame. Fans were rated at 1.4 $\mathrm{m}^{3} \cdot \mathrm{min}^{-1}$ providing complete air replacement about twice every minute. Comparison treatments were a full-sun control with plants grown on an open bench, and neutral shade treatments. Neutral shade was provided by covering frames with clear polyethylene and then cheesecloth to provide about $30 \%$ and $65 \%$ reductions in PAR, comparable to the degree of shading provided by the spectral filter film and the 115 lighting filter, respectively (Table 1). The use of cheesecloth as a shade material was shown to be neutral with respect to spectrum (Deitzer, unpublished data). Due to the limited availability of the 115 filter, frames for this treatment and the $65 \%$ neutral shade were $60 \mathrm{~cm}$ square and $55 \mathrm{~cm}$ tall, and were also equipped with electric exhaust fans. Shielded thermocouples were placed within each frame to monitor air temperature, and thermocouples were inserted into the flats to monitor soil temperature. Temperatures were recorded at 15-min intervals using a datalogger (CR-7; Campbell Scientific, Logan Utah).

Newly rooted runner tips of 'Chandler' strawberry in 50-cell trays were obtained from a commercial nursery in September 2001, and randomly assigned to each treatment. Plants were maintained in treatment conditions for four weeks and then transported on 5 Oct. to the University of Florida strawberry research station at Dover. Plants from each of the six treatments were set in four replicate 10-plant
Farms, Hurlock, Md.) and placed in treatment conditions during the week of 1 Aug. 2002. On 28 Aug., half of the treated plug plants were transplanted to the field at Beltsville in an annual hill-plasticulture production system. On 30 Aug., the remaining plants were transplanted into gutters in a commercial greenhouse in Mt. Airy, Md. There were insufficient plants of 'Allstar' in the AFR treatment for both field and greenhouse studies, so this treatment was not included in the greenhouse study.

For the Maryland field study, plants were plots and managed according to standard commercial practices for the Florida winter production system (Legard et al., 2001). Ripe fruit was harvested and weighed twice weekly through December and January to compare treatments for early fruiting.

Maryland. Based on the results from the first study, it was determined that plug conditioning treatments would again be evaluated in the winter production system in Florida, and in greenhouse and field production systems in Maryland. The AR, AFR, 30\% neutral shade, and full sun treatments were repeated. A short day treatment (SD) and continuous incandescent light treatment were also included. For the SD treatment, black cloth was removed and replaced from a PVC frame to provide an 8-h photoperiod. For the incandescent light treatment, a PVC frame was covered on four sides with black cloth and left open on the top to allow exposure to sunlight, and an incandescent light was placed in the top of the frame. Newly rooted runner tips of 'Chandler', 'Allstar', and 'Sweet Charlie' were obtained from a commercial nursery (Davon Crest placed in four replicate six-plant plots in a randomized complete block design on raised beds covered in black plastic mulch and managed as described previously (Black et al., 2002). Plants were evaluated for fall runner and crown development, and for fruit yield the following spring.

For the greenhouse study, a high density tunnel (HDT) production system was employed, with plants placed at $30 \mathrm{~cm}$ spacing in aluminum gutters filled with potting soil (Butler et al., 2002). The gutters were mounted on wooden stands, with eight gutters per bench. Benches were placed in a $9 \times 29 \mathrm{~m}$ greenhouse equipped with 1.2-m-high roll up sides for passive ventilation, and a propane heater used to maintain the air temperature above $3{ }^{\circ} \mathrm{C}$. The plants were fertilized weekly with a 20-20-20 fertilizer with micronutrients (Scotts, Marysville, Ohio). IPM monitoring was performed weekly, with applications of Oxidate (BioSafe Systems, Glastonbury, Conn.) used to control powdery mildew and Botrytis, and insecticidal soap to control aphids.

To avoid photo-degradation of the AR and

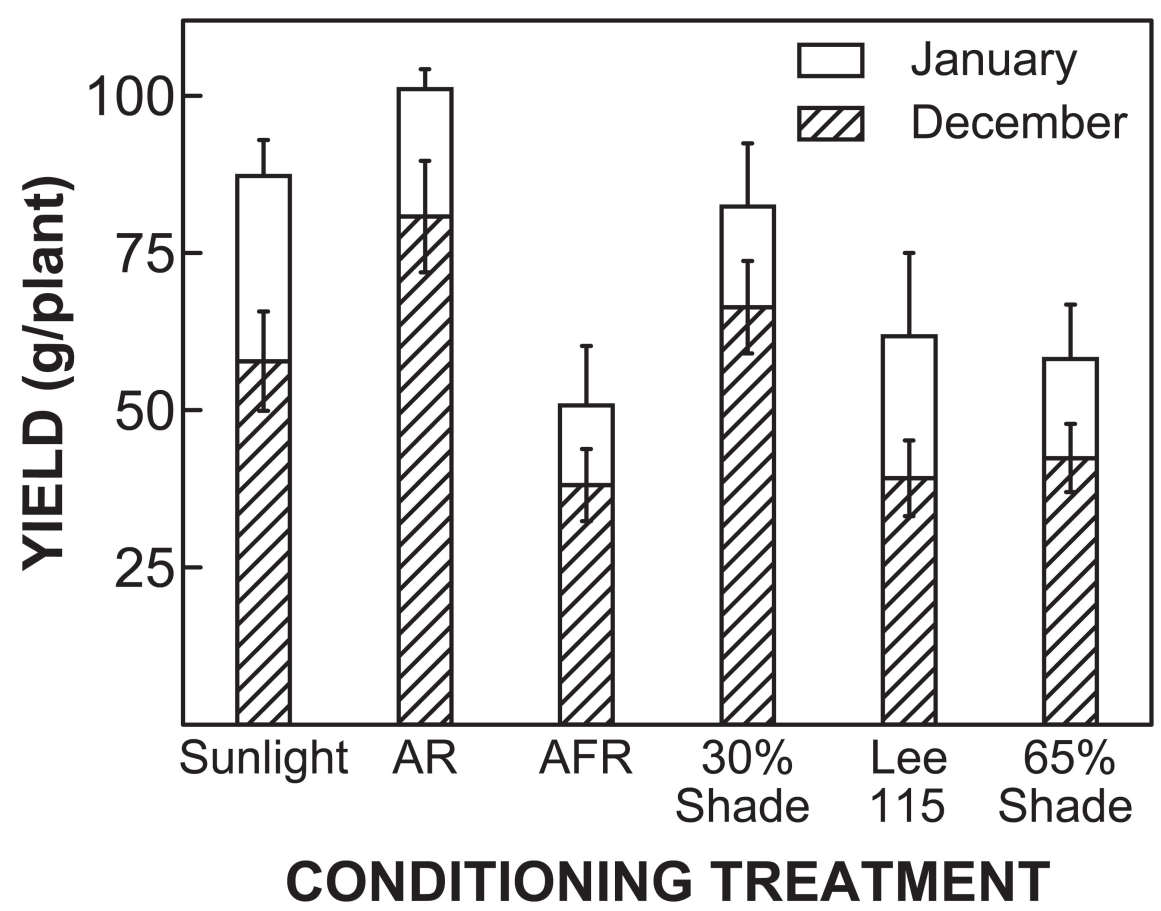

Fig. 1. Early-season fruit yield (December 2001 and January 2002) of 'Chandler' strawberry grown in Dover, Fla. Plants were subjected to 4 weeks of the specified conditions before transplanting to the fruiting field in Florida. Treatments included a red light filtering greenhouse film (AR), a far-red filtering greenhouse film (AFR), and a photographic red light filter (Lee 115). Comparison treatments were unfiltered sunlight, and neutral shade treatments corresponding to the level of PAR transmission for filtering films and filter. Values are means of four replications \pm standard errors. 
AFR greenhouse films, treatment chambers were disassembled and the films were stored in the dark between the conditioning periods. As a result, films were exposed to $<5$ months of sunlight throughout the course of the experiments.

Florida: Year 2. Runner tips of 'Chandler' and 'Sweet Charlie' were obtained from a commercial nursery (Norton Creek Farms, Cashiers, N.C.) in late August and placed in 48-cell packs under intermittent mist. On 11 Sept. 2002, the rooted tips were moved to the treatment conditions described above. On 7 Oct., plants were shipped to the research site in Dover for planting in the field. Plots were evaluated for both runner production and early fruiting.

Field plantings were arranged in a com- pletely randomized design. Statistical analysis was carried out using the GLM procedure of the statistical analysis software, SAS 8.2 (SAS Institute Inc., 1999). Data were analyzed as a light environment $\times$ cultivar factorial. Treatment means were separated using the PDIFF option of the LSMEANS statement.

\section{Results and Discussion}

Strawberry plants were provided with different light environments for a 4-week conditioning period, to determine whether these conditioning treatments would influence subsequent flowering or runnering in the field. Since temperature, and specifically root zone temperature influence strawberry growth and development (Geater et al., 1997), air and

Table 3. Effect of plug plant conditioning on runner production and branch crown formation in a greenhouse production system in Maryland. Plants were subjected to an altered light environment for 4 weeks before transplanting into a low-input greenhouse production system. Treatment $\times$ cultivar interaction was significant at $P=0.003$ for runner number, but not significant $(P>0.05)$ for crown number. Branch crowns are total crowns less the single original crown.

\begin{tabular}{|c|c|c|c|c|}
\hline \multirow[b]{2}{*}{ Treatment } & \multicolumn{3}{|c|}{ Cultivar } & \multirow[b]{2}{*}{ Mean } \\
\hline & Allstar & Chandler & Sweet Charlie & \\
\hline \multicolumn{5}{|l|}{ Runners per plant } \\
\hline Unfiltered sunlight & $0.17 \mathrm{a}$ & $2.01 \mathrm{ab}$ & $0.79 \mathrm{ab}$ & \\
\hline Red light filtering film & $0.61 \mathrm{a}$ & $2.81 \mathrm{abc}$ & $1.91 \mathrm{~b}$ & \\
\hline Far-red light filtering film & & $3.90 \mathrm{c}$ & $1.09 \mathrm{ab}$ & \\
\hline Neutral shade, $30 \%$ & $0.42 \mathrm{a}$ & $3.04 \mathrm{bc}$ & $3.27 \mathrm{c}$ & \\
\hline Incandescent light & $0.35 \mathrm{a}$ & $2.04 \mathrm{ab}$ & $1.23 \mathrm{ab}$ & \\
\hline Short day & $0.00 \mathrm{a}$ & $3.13 \mathrm{bc}$ & $1.47 \mathrm{ab}$ & \\
\hline \multicolumn{5}{|l|}{ Branch crowns per plant } \\
\hline Unfiltered sunlight & 0.78 & 0.31 & 0.75 & $0.61 \mathrm{ab}$ \\
\hline Red light filtering film & 0.72 & 0.17 & 0.52 & $0.47 \mathrm{ab}$ \\
\hline Far-red light filtering film & & 0.19 & 0.76 & \\
\hline Neutral shade, $30 \%$ & 0.22 & 0.13 & 0.40 & $0.25 \mathrm{~b}$ \\
\hline Incandescent light & 0.67 & 0.13 & 0.00 & $0.26 \mathrm{~b}$ \\
\hline Short day & 1.48 & 0.08 & 0.73 & $0.76 \mathrm{a}$ \\
\hline
\end{tabular}

Table 4. Effect of plug plant conditioning on fall runnering and branch crown formation in a cold climate annual hill system at Beltsville, Md. Plants were subjected to an altered light environment for 4 weeks before transplanting into the field. Treatment $\times$ cultivar interaction was significant at $P=0.011$ for runner number, but not significant $(P>0.05)$ for crown number. Branch crowns are total crowns less the single original crown.

\begin{tabular}{lllll}
\hline & \multicolumn{3}{c}{ Cultivar } & Mean \\
\cline { 2 - 3 } Treatment & Allstar & Chandler & Sweet Charlie & \\
\hline Runners per plant & & & & \\
Unfiltered sunlight & $0.50 \mathrm{abc}$ & $3.00 \mathrm{ab}$ & $2.00 \mathrm{a}$ \\
Red light filtering film & $1.04 \mathrm{bc}$ & $2.58 \mathrm{a}$ & $2.25 \mathrm{a}$ & \\
Far-red light filtering film & $0.33 \mathrm{ab}$ & $4.21 \mathrm{c}$ & $2.75 \mathrm{a}$ & \\
Neutral shade, 30\% & $1.08 \mathrm{bc}$ & $3.79 \mathrm{~b}$ & $2.41 \mathrm{a}$ & \\
Incandescent light & $1.31 \mathrm{c}$ & $3.46 \mathrm{bc}$ & $2.12 \mathrm{a}$ & \\
Short day & $0.08 \mathrm{a}$ & $3.83 \mathrm{c}$ & & $0.99 \mathrm{~b}$ \\
Branch crowns per plant & & & & $0.68 \mathrm{ab}$ \\
Unfiltered sunlight & 1.37 & 0.25 & 1.33 & $0.73 \mathrm{ab}$ \\
Red light filtering film & 0.67 & 0.29 & 1.08 & $0.40 \mathrm{a}$ \\
Far-red light filtering film & 0.96 & 0.17 & 0.71 & $0.62 \mathrm{a}$ \\
Neutral shade, 30\% & 0.46 & 0.04 & 1.03 & $1.00 \mathrm{~b}$ \\
Incandescent light & 0.71 & 0.13 & 1.50 & \\
Short day & 1.28 & 0.21 & & \\
\hline
\end{tabular}

Table 5. Effect of plug conditioning on runner numbers in the fruiting field in Florida before the 2002-03 season. Runners were counted and removed 14 Nov. (early), and 3 Dec. (late).

\begin{tabular}{|c|c|c|c|c|c|c|}
\hline \multirow[b]{2}{*}{ Treatment } & \multicolumn{3}{|c|}{ Chandler } & \multicolumn{3}{|c|}{ Sweet Charlie } \\
\hline & Early & Late & Total & Early & Late & Total \\
\hline Unfiltered sunlight & 2.38 & 2.80 & $5.18 \mathrm{a}$ & 2.70 & 0.50 & $3.20 \mathrm{a}$ \\
\hline Red light filtering film & 2.03 & 2.08 & $4.10 \mathrm{~b}$ & 1.65 & 0.28 & $1.93 \mathrm{bc}$ \\
\hline AFR, YXE-10 & 2.35 & 1.80 & $4.15 \mathrm{~b}$ & 1.18 & 0.28 & $1.45 \mathrm{c}$ \\
\hline Neutral shade, $30 \%$ & 2.18 & 1.68 & $3.85 \mathrm{~b}$ & 2.03 & 0.23 & $2.25 \mathrm{~b}$ \\
\hline Incandescent light & 1.78 & 2.05 & $3.83 \mathrm{~b}$ & 0.60 & 1.03 & $1.63 \mathrm{bc}$ \\
\hline Short day & 1.60 & 1.25 & $2.85 \mathrm{c}$ & 0.43 & 0.28 & $0.70 \mathrm{~d}$ \\
\hline
\end{tabular}

soil temperatures were recorded during the first experiment (Table 2). Minimum daily air temperatures ranged from 17.9 to $19.4^{\circ} \mathrm{C}$, with the lowest temperature in the full sun control. Among the enclosed frames, minimum air temperatures only differed by $0.4{ }^{\circ} \mathrm{C}$. Daily maximum air temperatures ranged from 27.6 ${ }^{\circ} \mathrm{C}$ for the $65 \%$ neutral shade, to $30.2{ }^{\circ} \mathrm{C}$ for the Lee 115 filter treatment, the two treatments with the smaller chamber volumes. Among the other treatments, the maximum air temperatures ranged from 29.2 to $29.9^{\circ} \mathrm{C}$. Minimum daily soil temperatures ranged from $17.8^{\circ} \mathrm{C}$ for the full sun control, to $19.2^{\circ} \mathrm{C}$ for the Lee 115 treatment. Among enclosed frame treatments, minimum soil temperature only differed by 0.2 ${ }^{\circ} \mathrm{C}$. Maximum daily soil temperatures ranged from $25.0^{\circ} \mathrm{C}$ for the $65 \%$ shade to $27.5^{\circ} \mathrm{C}$ for the AR treatment. Geater et al. (1997) reported maximum plant growth for soil temperatures at or below $29^{\circ} \mathrm{C}$, indicating that plant growth in the present study was not adversely affected by temperature conditions. Mean daily minimum temperatures were above $17^{\circ} \mathrm{C}$ and would not have been conducive to floral induction under long days. Both air and soil temperatures were similar among all treatments, likely resulting from the amount of airflow afforded by the exhaust fans placed in each frame.

Florida: Year 1. During the 2001-02 study, plants from the AR treatment showed symptoms of anthracnose crown rot (Colletotrichum) in the field, with 14 of the 40 plants succumbing to the disease. No visible disease symptoms were observed in the other treatments. Yields were calculated on a per-plant basis to account for these losses. Highest early yields were for the $\mathrm{AR}(\mathrm{R} / \mathrm{FR}=0.781)$ treatment and lowest early yields were for the FR-filtering AFR $(\mathrm{R} / \mathrm{FR}=1.57)$ treatment (Fig. 1). Since the yields for January were much lower than for December, treatment differences in total yield for the 2-month season were primarily determined by December yields. Based on the work of Collins (1966), a light environment with a low R/FR ratio should promote flowering. The AR treatment preferentially filters red light providing a low $\mathrm{R} / \mathrm{FR}$ environment, and produced the highest early yields in the 2001-02 study. Conversely, the AFR material filters far-red light providing a high R/FR environment, and gave lower early-season yields, suggesting that an altered R/FR environment could be used for conditioning plug plants. However, the Lee 115 $(\mathrm{R} / \mathrm{FR}=0.054)$ is a more efficient red light filter than AR, but the mean yield of plants in this treatment was among the lowest, and did not differ from the mean yield of plants in the $65 \%$ neutral shade treatment. Both of these treatments reduced PAR by $>50 \%$ compared to the AR and AFR treatments. It should also be noted that both the early and total-season yields of all plants in this trial were lower than those of commercially produced transplants (data not shown).

Maryland greenhouse study. Based on promising first-year results with the AR filter, additional experiments were initiated for the 2002-03 season. Plug plants of 'Allstar', 'Chandler', and 'Sweet Charlie' were conditioned in August and transplanted to green- 


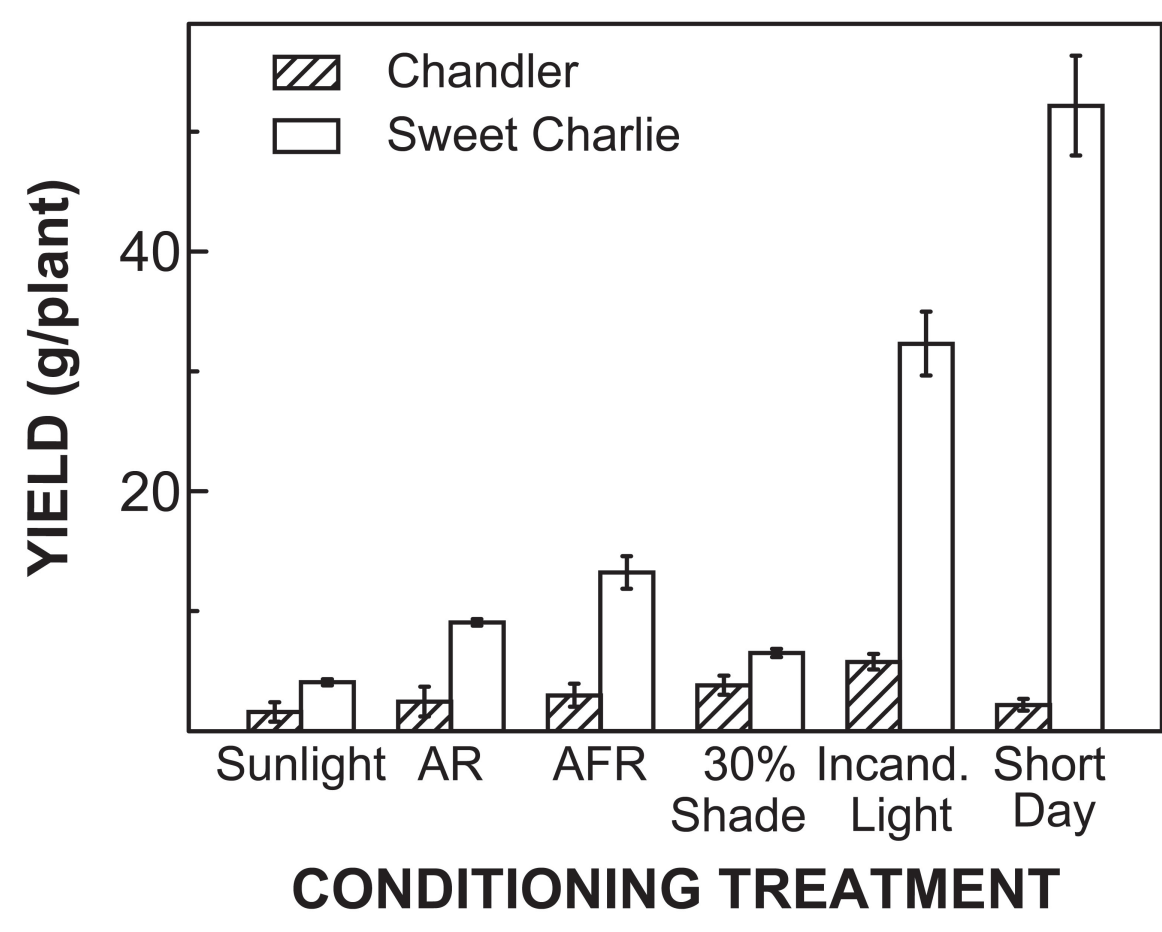

Fig. 2. Early-season yield (through 15 Jan.) of 'Chandler' and 'Sweet Charlie' strawberry grown in Dover, Fla., during the 2002-03 season. Plants were subjected to a 4-week conditioning period before transplanting into the fruiting field. Treatments included a red light filtering greenhouse film (AR), a far-red filtering greenhouse film (AFR), continuous incandescent light, and short day photoperiod provided by black curtains in the greenhouse. Comparison treatments were unfiltered sunlight, and a neutral shade treatment corresponding to the level of PAR transmission for the photoselective films. Values are means of four replications \pm standard errors.

house and field plots in Maryland. Plants in the greenhouse study were monitored periodically for runner production, branch crown formation, flowering and fruit set. Flowering and fruit set were extremely low among all plants in the study, and did not significantly differ among conditioning treatments. However, there were treatment differences in fall runner production and branch crown development (Table 3). Among cultivars, 'Chandler' had the highest number of runners and the fewest branch crowns, while 'Allstar' produced very few runners and had the highest number of branch crowns. Among conditioning treatments, the greatest amount of crown branching resulted from the SD treatment, with the most pronounced effect found with 'Allstar' and 'Sweet Charlie'.

Maryland field study. Plug plants from the conditioning treatments were transplanted to a field planting at Beltsville. Plots were evaluated in the fall for runnering and crown branching, and the following spring for yield. There were significant treatment differences in crown branching and runner production, with a significant treatment $\times$ cultivar interaction for runnering (Table 4). In crown branching, AR, AFR and incandescent light treatments did not differ from the neutral shade control. The most branch crown formation occurred in the SD treatment and the full sun control. Although the treatment $\times$ cultivar interaction term was not statistically significant for crown number, there were apparent differences in degree of response. The SD treatment for 'Allstar' had 1.28 branch crowns per plant (2.28 total crowns per plant) compared to 0.46 for the neutral shade control. By comparison, the SD treatment in 'Chandler' resulted in secondary crown formation in only one of five plants $(0.21$ branch crowns per plant) with no appreciable crown branching in the shaded control (0.04 branch crowns per plant). The spectral filter treatments were intermediate to the neutral shade and full-sun controls.

The 2003 harvest season was characterized by frequent rains and low temperatures. Despite a regular fungicide application program, yields were unusually low. Yields for both marketable and cull fruit were measured. The only the full sun control and the remaining treatments. There were no significant differences among treatments for fruit size or earliness (data not shown).

Florida: Year 2. Rooted runner tips of 'Chandler' and 'Sweet Charlie' were conditioned for four weeks during September, transplanted to the field in Florida, and monitored for runnering and early-season fruiting. For both cultivars, the highest number of runners was produced by the control, and the lowest number of runners was produced by plants receiving the short-day treatment (Table 5). Runner production did not differ significantly among the remaining treatments. Weather conditions were unseasonably cool, resulting in slow plant growth, delayed fruiting and low yields throughout the region. Early-season yields were better for 'Sweet Charlie' than for significant treatment difference was between
'Chandler'. Among conditioning treatments, plants in the short day treatment produced the highest early yield, followed by plants in the incandescent light treatment (Fig. 2).

\section{Conclusions}

Photoselective greenhouse films that preferentially filter red or far-red light have been tested for regulating growth of a number of plant species. The use of far-red filtering films has been particularly successful for reducing internode length in greenhouse-grown potted plants (Cerny et al., 2003; Khattak et al., 2004; Rajapakse et al., 1999; Runkle and Heins, 2002; Wilson and Rajapakse, 2001). Although far-red light is more effective at promoting flowering in LDP (Deitzer, 1984), Collins (1966) reported that SD strawberry flowered under continuous light when the light source had a low R/FR ratio. We hypothesized that a film that filtered red light, decreasing R/FR ratio, would promote flowering. Although initial results indicated that this might be possible, subsequent experiments did not confirm this. In fact, the use of black cloth curtains to provide 8-h photoperiods was more effective than spectral filters for reducing runnering, increasing branch crown formation, and promoting flowering. This suggests that an altered $\mathrm{R} / \mathrm{FR}$ environment is not sufficient to affect a SD response.

The three cultivars used in this study showed some differences in response to conditioning treatments. These differences were not surprising considering the fact that the cultivars were selected in very different environments. 'Allstar' is a northeastern selection developed for use in the matted row production system, but has also shown adaptability to cold-climate plasticulture (Black et al., 2002). 'Chandler' is a University of California release that is no longer planted widely in California or Florida, but has gained acceptance in cold climate plasticulture production in the midwestern and mid-Atlantic U.S. 'Sweet Charlie' is an early-fruiting cultivar from the University of Florida and is also grown somewhat in cold-climate plasticulture. The differences in response among cultivars may indicate differential sensitivity to photoperiod. Although all three cultivars are classified as June-bearing types (SDP), we have observed apparent differences in sensitivity to photoperiod among these cultivars. When plants are maintained under ambient light with supplemental heat, 'Allstar' and other eastern genotypes typically cease to produce new runners and leaves as days become shorter, while California and Florida genotypes will continued to grow (unpublished data). Although June-bearing strawberries are considered facultative SDP due to their response to both temperature and photoperiod signals, Galletta and Bringhurst (1989) suggested that modern cultivars are more responsive to temperature than to day length. This may explain the minimal response to the photoselective film and short day treatments in this study, and the genotypic differences in response. With plants grown above $20^{\circ} \mathrm{C}$, manipulation of R/FR light environment for four 
weeks before field planting was not sufficient to consistently advance flowering.

\section{Literature Cited}

Bish, E.B., D.J. Cantliffe, and C.K. Chandler. 2001. A system for producing large quantities of greenhouse-grown strawberry plantlets for plug production. HortTechnology 11:636-638.

Black, B.L. 2004. Prohexadione-calcium decreases fall runners and advances branch crowns of 'Chandler' strawberry in a cold-climate annual production system. J. Amer. Soc. Hort. Sci. 129:479-485.

Black, B.L., J.M. Enns, and S.C. Hokanson. 2002. A comparison of temperate-climate strawberry production systems using eastern genotypes. HortTechnology 12:670-675.

Borthwick, H.A., S.B. Hendricks, and M.W. Parker. 1952. The reaction controlling floral initiation. Proc. Nat. Acad. Sci. USA 38:929-934.

Butler, B.R., H.J. Swartz, and D. Lankford. 2002. High tunnels extend season and allow winter protection. Veg. Growers News 36(6):8-10.

Cerny, T.A., J.E. Faust, D.R. Layne, and N.C. Rajapakse. 2003. Influence of photoselective films and growing season on stem growth and flowering of six plant species. J. Amer. Soc. Hort. Sci. 128:486-491.

Collins, W.B. 1966. Floral initiation in strawberry and some effects of red and far-red radiation as components of continuous white light. Can. J. Bot. 44:663-668.

Collins, W.B. and W.G. Barker. 1964. A flowering response of strawberry to continuous light. Can. J. Bot. 42:1309-1311.

Darnell, R.L., D.J. Cantliffe, D.S. Kirschbaum, and C.K. Chandler. 2003. The physiology of flower- ing in strawberry. Hort. Rev. 28:325-349.

Darrow, G.M. 1936. Interrelation of temperature and photoperiodism in the production of fruit-buds and runners in strawberry. Proc. Amer. Soc. Hort. Sci. 34:360-363.

Darrow, G.M. 1955a. Effect of temperature and day length on varietal adaptation of strawberry (part I). Fruit Var. Hort. Dig. 10:37-40.

Darrow, G.M. 1955b. Effect of temperature and day length on varietal adaptation of strawberry (part II). Fruit Var. Hort. Dig. 10:51-54.

Deitzer G.F. 1984. Effect of far-red energy on the photoperiodic control of flowering in Wintex barley (Hordeum vulgare L.), p. 99-116. In: W. Meudt (ed.). Strategies of plant reproduction. Allenheld-Osmun, Totowa, N.J.

Durner, E.F., J.A. Barden, D.G. Himelrick, and E.B. Poling. 1984. Photoperiod and temperature effects on flower and runner development in dayneutral, junebearing, and everbearing strawberries. J. Amer. Soc. Hort. Sci. 109:396-400.

Durner, E.F. and E.B. Poling. 1988. Strawberry developmental responses to photoperiod and temperature: A review. Adv. Strawberry Prod. 7:6-15.

Galletta, G.J. and R.S. Bringhurst. 1989. Strawberry management, p. 83-156. In: G.J. Galletta and D.G. Himelrick (eds.). Small fruit crop management. Prentice Hall, Englewood Cliffs, N.J.

Geater, C.A., G.R. Nonnecke, W.R. Graves, A.S. Aiello, and C.A. Dilley. 1997. High root-zone temperatures inhibit growth and development of Fragaria species. Fruit Var. J. 51(2): 94-101.

Hartmann, H.T. 1947. The influence of temperature on the photoperiodic response of several strawberry varieties grown under controlled environment conditions. Proc. Amer. Soc. Hort. Sci. 50:243-245.
Hokanson, S.C., F. Takeda, J.M. Enns, and B.L. Black. 2004. Influence of plant storage duration on strawberry runner tip viability and field performance. HortScience 39:1596-1600.

Holmes, M.G. and H. Smith. 1977. The function of phytochrome in the natural environment. IV. Light quality and plant development. Photochem. Photobiol. 25:551-556.

Khattak, A.M., S. Pearson, and C.B. Johnson. 2004. The effects of far red spectral filters and plant density on the growth and development of chrysanthemums. Scientia Hort. 102:335-341.

Legard, D.E., G.J. Hochmuth, W.M. Stall, J.R. Duval, J.F. Price, T.G. Taylor, and S.A. Smith. 2001. Strawberry production in Florida, p. 237-241. In: D.N. Maynard and E.A. Simonne (eds.). Vegetable production guide for Florida. UF-IFAS Press, Gainesville.

Rajapakse, N.C., R.E. Young, M.J. McMahon, and R. Oi. 1999. Plant height control by photoselective filters: current status and future opportunities. HortTechnology 9:618-624.

Runkle, E.S. and R.D. Heins. 2001. Specific functions of red, far red, and blue light in flowering and stem extension of long-day plants. J. Amer. Soc. Hort. Sci. 126:275-282.

Runkle, E.S. and R.D. Heins. 2002. Stem extension and subsequent flowering of seedlings grown under a film creating a far-red deficient environment. Scientia Hort. 96:257-265.

SAS Institute Inc. 1999. SAS Online Doc. Version 8, SAS Institute Inc., Cary, N.C.

Sonsteby, A. and A. Nes. 1998. Short days and temperature effects on growth and flowering in strawberry (Fragaria $\times$ ananassa Duch.). J. Hort. Sci. Biotechnol. 73:730-736.

Wilson, S.B. and N.C. Rajapakse. 2001. Growth control of Lisianthus by photoselective plastic films. HortTechnology 11:581-584. 